\title{
MAMELE CU COPII DE VÂRSTĂ PREȘCOLARĂ: ÎNTRE SERVICIU ȘI OBLIGAȚIUNI FAMILIALE
}

\author{
Inga CHISTRUGA-SÎNCHEVICI ${ }^{\circledR}$, doctor în sociologie, \\ Centrul de Cercetări Demografice al INCE, Republica Moldova \\ Natalia BARGAN ${ }^{\odot}$, cercetător științific, \\ Centrul de Cercetări Demografice al INCE, Republica Moldova
}

DOI: https://doi.org/10.36004/nier.cdr.2019.14-06

JEL CLASSIFICATION: J10, J12, J13.

\begin{abstract}
Munca și viața de familie nu mai sunt două lucruri distincte, ci sunt interconectate. Interesul profund pentru relaţia dintre viaţa profesională și cea familială se datorează factorilor de natură sociodemografică - creşterea numărului de cupluri în care ambii parteneri sunt angajaţi, a numărului de familii cu un singur părinte, a numărului de femei angajate, dar şi accentuarea importanţei identităţii profesionale pentru femei. Articolul este elaborat în baza studiului sociologic calitativ "Părinții între necesitatea de a munci și responsabilitățile familiale" efectuat și studiului cantitativ "Părinții între necesitatea de a munci și responsabilitățile familiale" (1047 de chestionare cu mame cu copii de vârstă preșcolară), desfășurate de CCD al INCE. Rezultatele cercetării au relevat că între muncă și familie apar diferite forme a unui anumit conflict - conflict datorat timpului, tensiunii şi comportamentului. In absența unor facilități de echilibrare a vieții profesionale și a celei familiale, strategia multor femei este reducerea numărului de nașteri sau amânarea lor. Situația creată impune implementarea măsurilor de facilitare a îmbinării rolurilor conjugale și profesionale de către mamele cu copiii de vârstă preșcolară.
\end{abstract}

Cuvinte-cheie: copil, familie, piața muncii, reconciliere, viață profesională.

Work and family life are no longer two distinct things but are interconnected. The deep interest in the relationship between work and family life is due to socio-demographic factors - the increased number of couples in which both partners are employed, the number of families with a single parent, the number of employed women, but also the highlighting of the importance of women's professional identity. The article is based on the qualitative sociological study "Parents between the need to work and family responsibilities" and the quantitative study "Parents between the need to work and family responsibilities" (1047 questionnaires with mothers with preschool children) conducted by CDR at NIER. The results of the study revealed that between work and family there are different forms of certain conflict - conflict due to time, tension and behaviour. In the absence of facilities for balancing professional and family life, the strategy of many women is to reduce number of births or delay these. The created situation requires the implementation of measures to facilitate the combination of marital and professional roles by mothers with preschool children.

Key words: child, family, labor market, reconciliation, professional life.

Sarcinile de combinare a rolurilor profesionale și familiale sunt astăzi obiectivele politicii sociale de stat. În Programul Naţional Strategic în domeniul securităţii demografice a Republicii Moldova (2011-2025) se specifică că, în scopul dezvoltării măsurilor de soluţionare a problemelor familiei, se propune promovarea implicării mai largi a tatălui în creşterea copiilor prin acordarea concediului plătit de paternitate şi a concediului pentru creşterea copilului cu prevederi speciale pentru taţi; stabilirea unui program de muncă flexibil pentru a facilita procesul de creştere a copiilor; asigurarea plăţii/remunerării egale pentru femei şi barbaţi.

\footnotetext{
๑) Inga Chistruga-Sînchevici, i_sinchevici@yahoo.com

๑ Natalia Bargan, nataly_bargan@gmail.com
} 
De asemenea au fost operate mai multe schimbări la cadrul legal. Potrivit modificărilor la Legea privind indemnizaţiile pentru incapacitate temporară de muncă şi alte prestaţii de asigurări sociale din 1 iulie 2019, părinții care beneficiază de indemnizații pentru creșterea copilului dar decid să se încadreze în câmpul muncii, vor primi și indemnizația, și salariul. S-a reformat concediul de îngrijire a copiilor prin majorarea îndemnizației pentru creșterea copilului proporțional cu reducerea perioadei concediului de îngrijire. Alte modificări țin de reducerea concediul de îngrijire neplătit de la 6 ani la 4 ani și completarea Codului Muncii cu art. $124^{1}$ Concediul paternal.

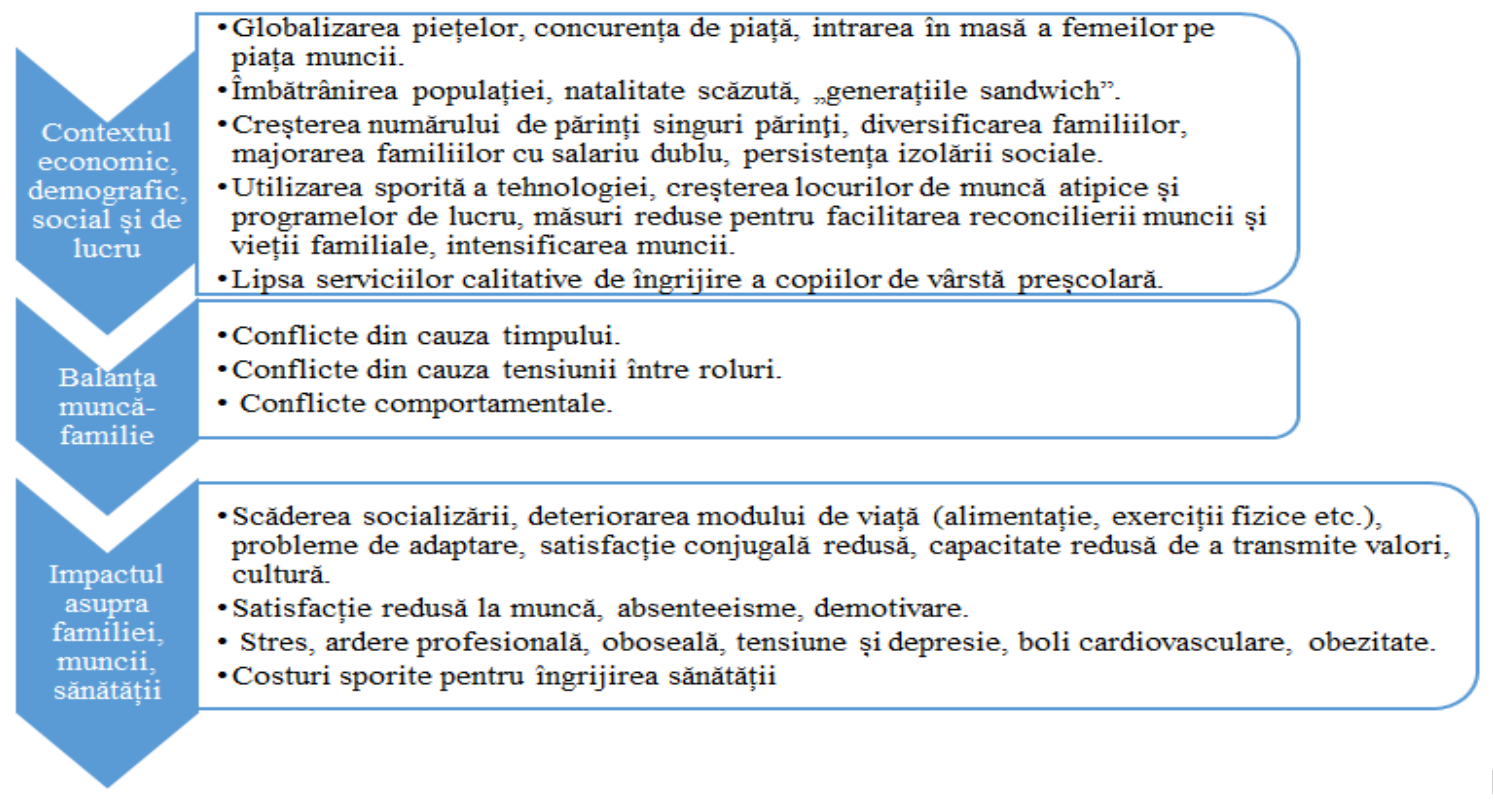

Figura 1. Echilibrul dintre componentele muncă și familie

Sursa: Elaborate de autorii

În societatea actuală plină de responsabilități și angajamente, echilibrul dintre muncă și viața familială a devenit o problemă predominantă. Echilibrul dintre aceste două componente înseamnă alocarea unui interval de timp egal ambelor segmente de viată, evitând defavorizarea unuia dintre ele în fața celuilalt. Acest echilibru nu vine de la sine și este rezultatul unei bune organizări și a disciplinei.

Obținerea echilibrului dintre serviciu și familie este benefică atât pentru sănătatea şi starea de bine a angajaţilor, precum şi pentru performanţa organizaţională (intensificarea productivităţii, diminuarea absenteismului). La nivel societal, beneficiile sunt creşterea ratelor de ocupare ale femeilor şi de fertilitate.

Articolul este elaborat în baza studiului sociologic calitativ "Părinții între necesitatea de a munci și responsabilitățile familiale" efectuat în perioada august-octombrie 2018 de către Centrul de Cercetări Demografice al INCE, în cadrul căruia au fost realizate 20 de interviuri sociologice cu mame cu copii de vârstă preșcolară (până la 6 ani). De asemenea la baza articolului mai stau și datele studiului cantitativ "Părinții între necesitatea de a munci și responsabilitățile familiale" (1047 de chestionare cu mame cu copii de vârstă preșcolară), desfășurat în perioada februarie-martie 2019 în muncipiul Chișinău. S-a optat pentru realizarea studiului doar în municipiul Chișinău din mai multe considerente: persistența problemelor demografice: creșterea vârstei la nașterea copiilor; intensificarea fenomenului de maternitate amânată; lipsa serviciilor calitative de educație preșcolară, îndeosebi pentru copiii de vârstă fragedă; în majoritatea familiilor ambii parteneri sunt angajați în câmpul muncii; majorarea numărului de familii cu un singur părinte; concentarea populației tinere, familiilor tinere, familiilor cu copii mici; posibilități extinse de încadrare în câmpul muncii; nivelul înalt de instruire al populației feminine. 
Cercetătorii au făcut diferenţă între două direcţii ale conflictului dintre muncă şi familie: conflictul muncă-familie şi conflictul familie-muncă. Conflictul muncă-familie apare atunci când activităţile legate de serviciu se intersectează cu responsabilităţile casnice, iar conflictul familiemuncă apare atunci când responsabilităţile familiale împiedică activităţile de la serviciu. Deşi sunt strâns legate între ele, sunt construcţii distincte din punct de vedere conceptual şi empiric. Conflictul muncă-familie este generat în contextul actual și de anumiți factori specifici ce țin de evoluția tehnologiilor. În viaţa profesională contemporană, noile tehnologii permit realizarea sarcinilor profesionale nu numai în locaţii diverse, ci şi în afara timpului oficial de lucru. Presiunea de a respecta termene limită din ce în ce mai stricte, precum şi necesitatea de a fi în permanenţă la dispoziţia clienţilor, au condus la extinderea vieţii profesionale spre cea familială.

Tabelul 1. Valoarea conflictului muncă-familie

\begin{tabular}{|l|c|c|}
\hline & $\mathrm{X}$ & $\mathrm{S}$ \\
\hline $\begin{array}{l}\text { 1. Deoarece am multe sarcini și responsabilități la locul de muncă, nu pot petrece } \\
\text { timp suficient cu familia mea }\end{array}$ & 2,66 & 1,086 \\
\hline $\begin{array}{l}\text { 2. Oboseala fizică și psihică la locul de muncă face dificilă îndeplinirea } \\
\text { responsabilităților mele la domiciliu }\end{array}$ & 2,72 & 1,043 \\
\hline 3. Oboseala de la locul de muncă scade răbdarea mea față de membrii familiei & 2,38 & 1,073 \\
\hline $\begin{array}{l}\text { 4. Atribuțiile de la locul de muncă mă face să mă simt obosită în timp ce îmi } \\
\text { îndeplinesc responsabilitățile acasă }\end{array}$ & 2,66 & 1,052 \\
\hline $\begin{array}{l}\text { 5. Nu pot să utilizez timpul pentru treburile casnice datorită serviciului meu. } \\
\text { Întotdeauna amân efectuarea lucrului casnic }\end{array}$ & 2,32 & 1,087 \\
\hline $\begin{array}{l}\text { 6. Viața mea profesională îmi diminuează eforturile necesare pentru îndeplinirea } \\
\text { responsabilităților mele casnice }\end{array}$ & 2,29 & 1,083 \\
\hline $\begin{array}{l}\text { 7. Continui acasă să mă gândesc la o problemă cu care m-am confruntat la locul de } \\
\text { muncă }\end{array}$ & 2,63 & 1,119 \\
\hline 8. O problemă de la serviciu mă face să fiu stresată și nervoasă acasă & 2,44 & 1,067 \\
\hline $\begin{array}{l}\text { 9. Atribuțiile și responsabilitățile mele la locul de muncă sunt prioritare vieții mele } \\
\text { de familie }\end{array}$ & 1,82 & 1,158 \\
\hline Total & 21,92 & 9,76 \\
\hline
\end{tabular}

Sursa: Calculele autorilor

Pentru evaluarea indicatorilor conflictului familie-muncă și muncă familie s-a realizat o revizuire a literaturii, utilizându-se scalele propuse de cercetătorii turci Gürcü Erdamar și Hüsne Demirel [4], care au fost traduse și adaptate. Fiecare întrebare a fost răspunsă ca Niciodată (1), Rar (2), Ocazional (3), Adesea (4) şi Întotdeauna (5). Rezultatele studiului denotă că valoarea conflictului familie-muncă este mai mare decât cea a conflictului muncă-familie, fiind de 25,4 și respectiv de 21,92 . 
Tabelul 2. Valoarea conflictului familie-muncă

\begin{tabular}{|l|c|c|}
\hline & $\mathrm{X}$ & $\mathrm{S}$ \\
\hline $\begin{array}{l}\text { 1. Responsabilitățile mele de acasă diminuează timpul și efortul pe care ar trebui să } \\
\text { le acord activității profesionale }\end{array}$ & 2,01 & 0,970 \\
\hline $\begin{array}{l}\text { 2. Deoarece am prea multe responsabilități la domiciliu, nu pun locul de muncă în } \\
\text { prim-plan }\end{array}$ & 2,22 & 1,075 \\
\hline 3. Responsabilitățile mele la domiciliu creează dificultăți în viața mea profesională & 1,83 & 0,952 \\
\hline 4. Necazurile și problemele din familie afectează negativ viața mea profesională & 1,81 & 0,960 \\
\hline 5. O problemă din familie mă face să mă simt stresată și nervoasă la locul de muncă & 2,07 & 1,006 \\
\hline $\begin{array}{l}\text { 6. La locul de muncă continui să mă gândesc la o problemă cu care m-am confruntat } \\
\text { acasă }\end{array}$ & 2,42 & 1,019 \\
\hline $\begin{array}{l}\text { 7. Anumite situații întâlnite acasă (oaspeți, boală, o problemă legată de copil) fac } \\
\text { munca mea dificilă }\end{array}$ & 2,43 & 0,994 \\
\hline $\begin{array}{l}\text { 8. Sarcinile casnice reduc timpul pe care îl am pentru somn, care este esențial pentru } \\
\text { serviciul meu }\end{array}$ & 2,55 & 1,140 \\
\hline 9. Datorită responsabilităților mele din familie, mă duc mereu la lucru obosită & 2,22 & 1,027 \\
\hline $\begin{array}{l}\text { 10. Datorită responsabilităților mele din familie, nu pot participa la anumite } \\
\text { activități legate de activitatea mea profesională (întâlnire, cina etc.) }\end{array}$ & 2,28 & 1,128 \\
\hline $\begin{array}{l}\text { 11. Atribuțiile și responsabilitățile mele din familie sunt mai presus de viața mea } \\
\text { profesională }\end{array}$ & 3,56 & 1,395 \\
\hline Total & 25,4 & 11,66 \\
\hline
\end{tabular}

Sursa: Calculele autorilor

Datele din Fig. 2. relevă că valoarea conflictului la ambele componente muncă-familie și familie-muncă este mai înaltă la mamele care au copii cu vârsta de până la 3 ani, decât la mamele care au copii de la 3 până la 7 ani.

Prezența copiilor cu vârsta de la 3 până la 7 ani

Prezența copiilor cu vârsta de până la 3 ani
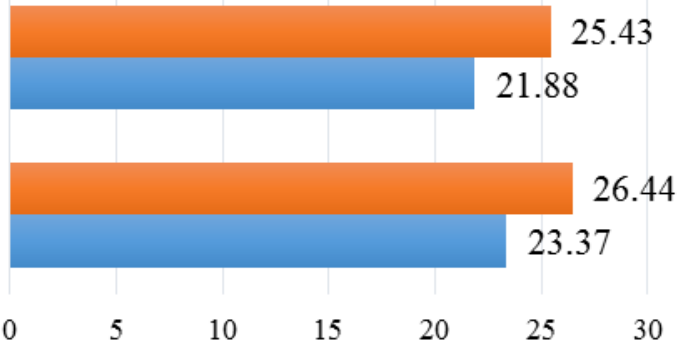

v Valoarea conflictului familie-muncă $\quad$ valoarea conflictului muncă-familie

Figura 2. Valoarea conflictului familie-muncă și muncă-familie în funcție de vârsta copiilor

Sursa: Calculele autorilor

Potrivit datelor studiului, principalul motiv care determină mamele să revină în câmpul muncii este necesitatea de a câștiga bani (49,3\%). "Dacă ar avea cine să ne întrețină, aș sta până la 3 ani acasă cu copilul. Îmi este jale de el, când trebuie să plec la serviciu, vine la mine și nu vrea să mă lase". 


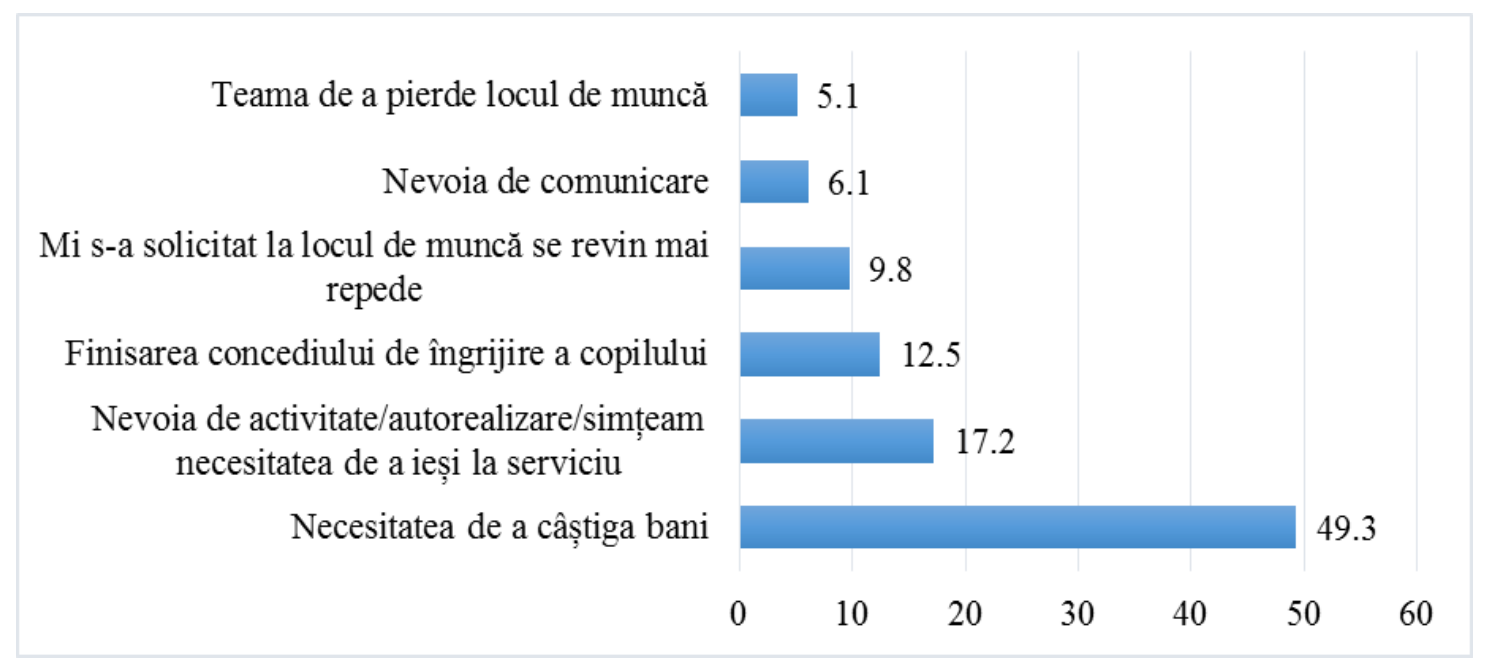

Figura 3. Motivele revenirii în câmpul muncii a mamelor cu copii de vârstă preșcolară

Sursa: Calculele autorilor

Din totalul celor care au revenit în câmpul muncii 35,4\% și-au schimbat locul de muncă, preponderent și-au schimbat locul de muncă persoanele care activau în sectorul privat al economiei. Acest aspect evidențiază persistența insecurității sporite în companiile private. Astfel, unele femei intenționat aleg/dau preferință mediului public pentru a beneficia de concedii de maternitate, de îngrijire a copilului și concedii medicale. „Eu știu că la privat nu se prea respectă drepturile cu privire la maternitate, de aceea am decis să mă angajez la stat, unde sigur sunt respectate drepturile mamelor cu copii. Colegele mi-au dat de ințeles că, dacă în viitor vreau să am copii, atunci aş face bine să plec de aici. Am constatat că la privat la noi în țară nu poți fi mamă”. „Mai bine lucrez într-o instituție de stat cu un salariu mai mic, dar să fiu respectată, să mă simt om, și nu la particulari cu bani mai mulți, dar considerată mașină de făcut bani, care, dacă se uzează, o arunci". Datele din Fig. 4. accentuiază unele probleme ce se atestă în mediul privat, precum ocuparea funcției deținute anterior de către alte persoane contrar cadrului legal care asigură păstrarea locului de muncă la revenirea din concediul de îngrijire a copilului și lipsa de perspective de creștere profesională.

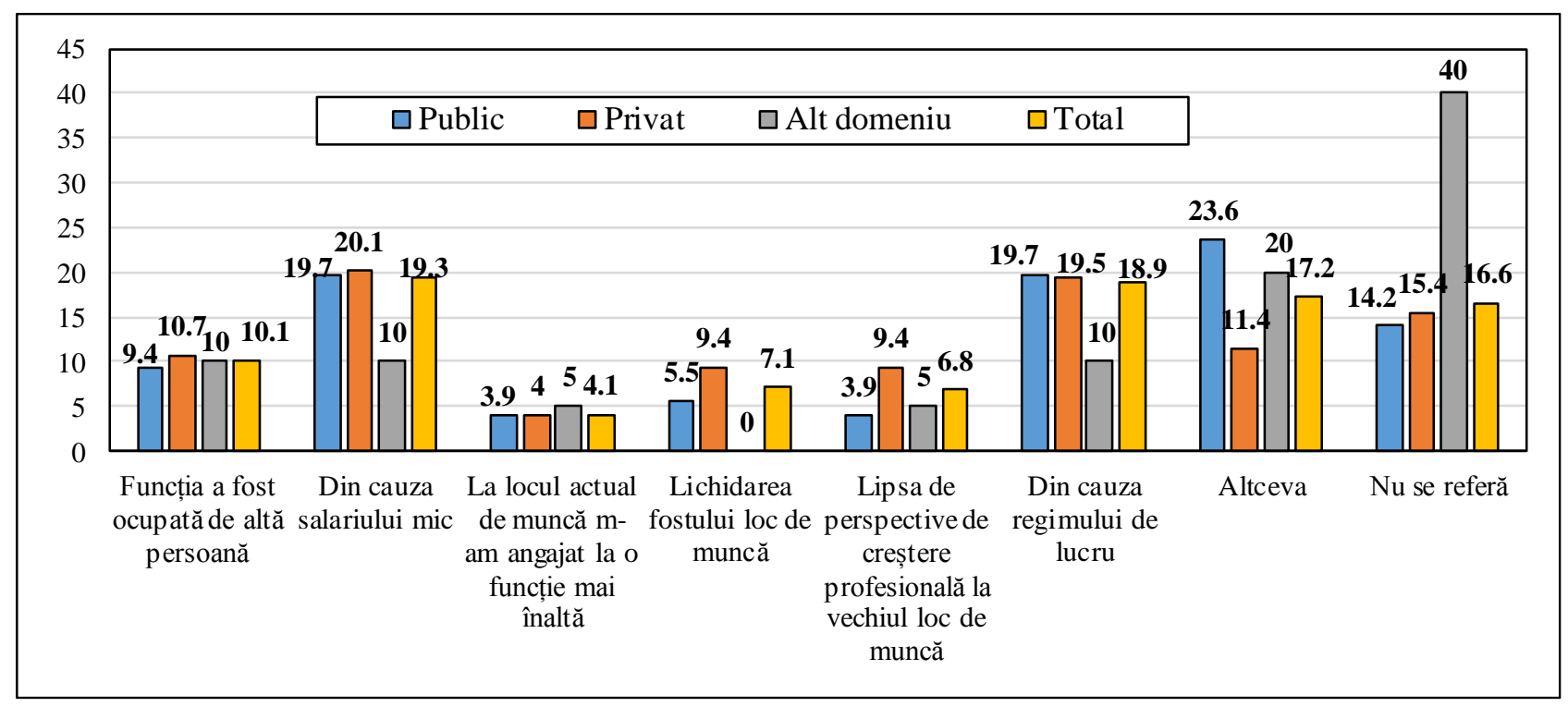

Sursa: Calculele autorilor

Figura 4. Cauzele schimbării locului de muncă 
Datele studiului ne-a permis elaborarea tipologiei mamelor cu copii de vârstă preșcolară în funcție de orientările lor profesionale și familiale și caracterizarea acestora:

Mame care își doresc să combine serviciul cu creșterea copiilor (65\%) - majoritatea dintre ele aveau statutul de angajate (salariate); activează în domeniul public; stagiul de activitate este redus; preponderent revin în câmpul muncii după finalizarea concediului de îngrijire a copilului. Apreciază că îmbină armonios munca cu viața de familie. S-a evidențiat că cele mai multe dintre ele consideră că le place să muncească, dar nu-și doresc o activitate profesională prea solicitantă. Pentru mamele din această categorie munca este doar o sursă de venit pentru viață.

Mame care intenționează să facă carieră dar să nu uite nici de copii $(21,3 \%)$ - de obicei au un nivel de instruire superior; ocupă funcții de conducere; cele mai multe activează în sectorul privat al economiei; durata aflării în concediu de îngrijire a copilului este mică. Apelează la servicii particulare de îngirijire a copilului. Recunosc că sunt mai dedicate domeniului de activitate decât vieții de familie. Beneficiază de suportul/susținerea necesară a soțului la revenirea în câmpul muncii. Sunt foarte satisfăcute de serviciul la care sunt angajate.

Mame care intenționează să fie casnică și să aibă grijă de copii $(13,7 \%)$ - cele mai multe au studii gimnaziale, medii, medii speciale; au trei și mai mulți copii; majoritatea ocupă funcții de execuție; preponderent activează în domeniile industrie prelucrătoare și comerț; un număr important dintre ele activează până la 6 ore pe zi. Mai mult de jumătate dintre ele și-au schimbat locul de muncă după aflarea în concediu de îngrijire a copilului. Soțul, în majoritatea cazurilor, este principalul întreținător al familiei și tot el este cel care cel mai adesea ia deciziile ce țin de gospodărie. Recunosc că sunt mai dedicate copiilor și mai mulțumite de calitatea de părinte, în detrimentul carierei.

Mamele intervievate au evidenţiat un nivel ridicat de motivaţie pentru a fi încadrate în câmpul muncii. Astfel, 45,2\% și-au dorit/își doresc să reînceapă lucrul înainte ca copilul să împlinească vârsta de 3 ani. Unii însă consideră că cariera unei femei va afecta dezvoltarea personalității copiilor ei. Lipsa atenției materne le pot afecta dezvoltarea personală, le pot complica relaţia cu mama.

10,2\% din părinți și-ar fi dorit să dea copilul la grădiniță până la vârsta de 2 ani, 57,4\% între 2 și 3 ani, și restul - după vârsta de 3 ani. Însă, în 2018 din totalul copiilor cuprinși în instituțiile de învățământ preșcolar din mun. Chișinău 91,1\% aveau vârsta peste 3 ani și doar 8,9\% până la 3 ani. Aceasta denotă lipsa segmentului de servicii pentru îngrijirea copiilor până la vârsta de 3 ani şi imposibilitatea părinţilor cu copii de a se reîncadra peste puţin timp în câmpul muncii.

Doar 59\% din mamele cu copii de vârstă preșcolară au menționat că au avut siguranța că pot lăsa copilul mic în grija cuiva până la revenirea de la serviciu, știind că totul va fí bine. "Soțul nu $a$ fost de acord să o dau așa devreme la grădiniță. Eu nu eram liniștităa deoarece era un singur educator și fără dădacă. Îmi dădeam seama că lucrurile nu mergeau chiar bine, dar nu aveam altă soluție. Ca să o dau la o grădiniță privată nu puteam din cauza salariilor noastre să ne permitem, ca să stea părinții noștri tot nu era posibil, fiindcă ei lucrează". 


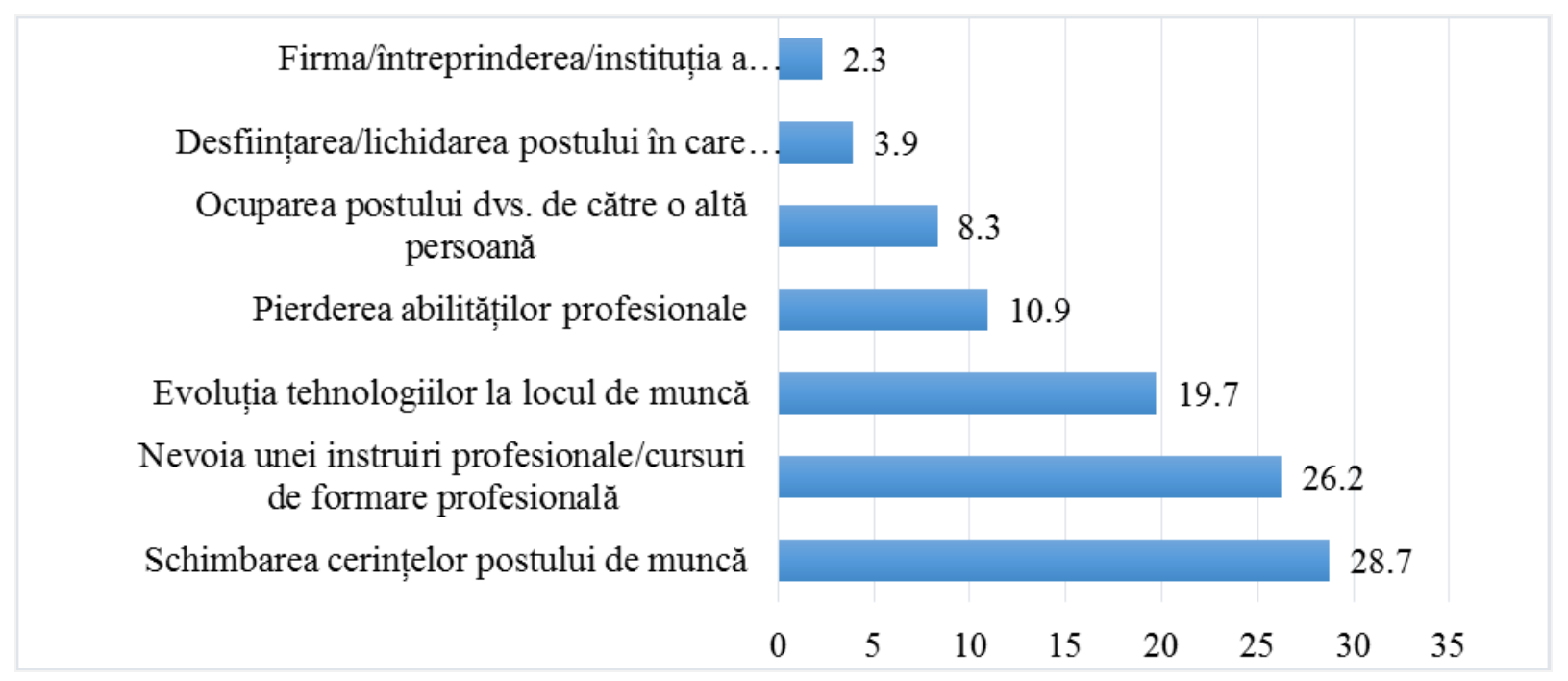

\section{Figura 5. Dificultăți cu care s-au confruntat mamele în reintegrarea profesională odată cu revenirea din concediul de îngrijire a copilului}

Sursa: Calculele autorilor

Potrivit datelor studiului cantitativ, schimbarea cerințelor postului de muncă și nevoia unei instruiri profesionale sunt principalele dificultăți cu care se confruntă. Alte dificultăți au fost identificate în cadrul interviurilor realizate:

Munca în ture. "Nu sunt bune serviciile de noapte nici pentru mine, nici pentru copii".

Îmbolnăvirile frecvente ale copilului. "Au fost situații că am dus copilul bolnav la grădiniță. Șefa ne-a spus în față: aveți copii - stați acasă, nu vreți să stați - luați dădacă, nu aveți posibilitatea să luați dădacă, înseamnă că stați voi". Numărul total de zile, pe parcursul ultimelor 3 luni, în care respondentele au lipsit de la serviciu aflându-se în concediu medical de îngrijire a copilului constituie 4099. 49,5\% din respondente au declarat că au fost situaţii în ultimele 3 luni să lucreze, deși ar fi trebuit să-și ia concediu medical din cauza stării de sănătate a copilului.

Dificultăți în îndeplinirea sarcinilor profesionale. "La început a fost greu, era necesar să intru în temă, deoarece zilnic se făceau diferite actualizări de cifre".

Necesitatea reținerii la serviciu pentru realizarea activităților de serviciu. „Sunt anumite perioade, specifice genului de activitate, datorită cărora programul de muncă durează până la 1012 ore zilnic". "Rămân uneori peste program din cauza lipsei cadrelor și volumului mare de lucru".

Reticența unor angajatori de a încadra în câmpul muncii mame cu copii mici. „Nimeni nu vrea să te ia la lucru știind că trebuie să te ceri des de la serviciu. Eu am apelat la patru firme, care au procese de producere și nu are cine te înlocui dacă ai nevoie urgent să pleci”".

Refuzul avansării în carieră pe motiv de sarcină și de îngrijire a copilului. „Cu 2 luni inainte de naștere am participat la un concurs pentru o funcție publică. Unii membri ai comisiei nu au susținut candidatura mea, din motivul că voi merge să nasc și voi uita de birou”."

Posibilități limitate de muncă part-time pentru mame. "Inițial, îmi doream să lucrez pe jumătate de normă, adică 4 ore, dar nu mi s-a permis. Mi s-a spus ori de tot, ori deloc".

Potrivit opiniilor mamelor intervievate, majoritatea angajatorilor nu sustin introducerea programelor flexibile de muncă și munca part-time. În Franța, 30 la sută din femeile care lucrează au locuri de muncă cu jumătate de normă. 


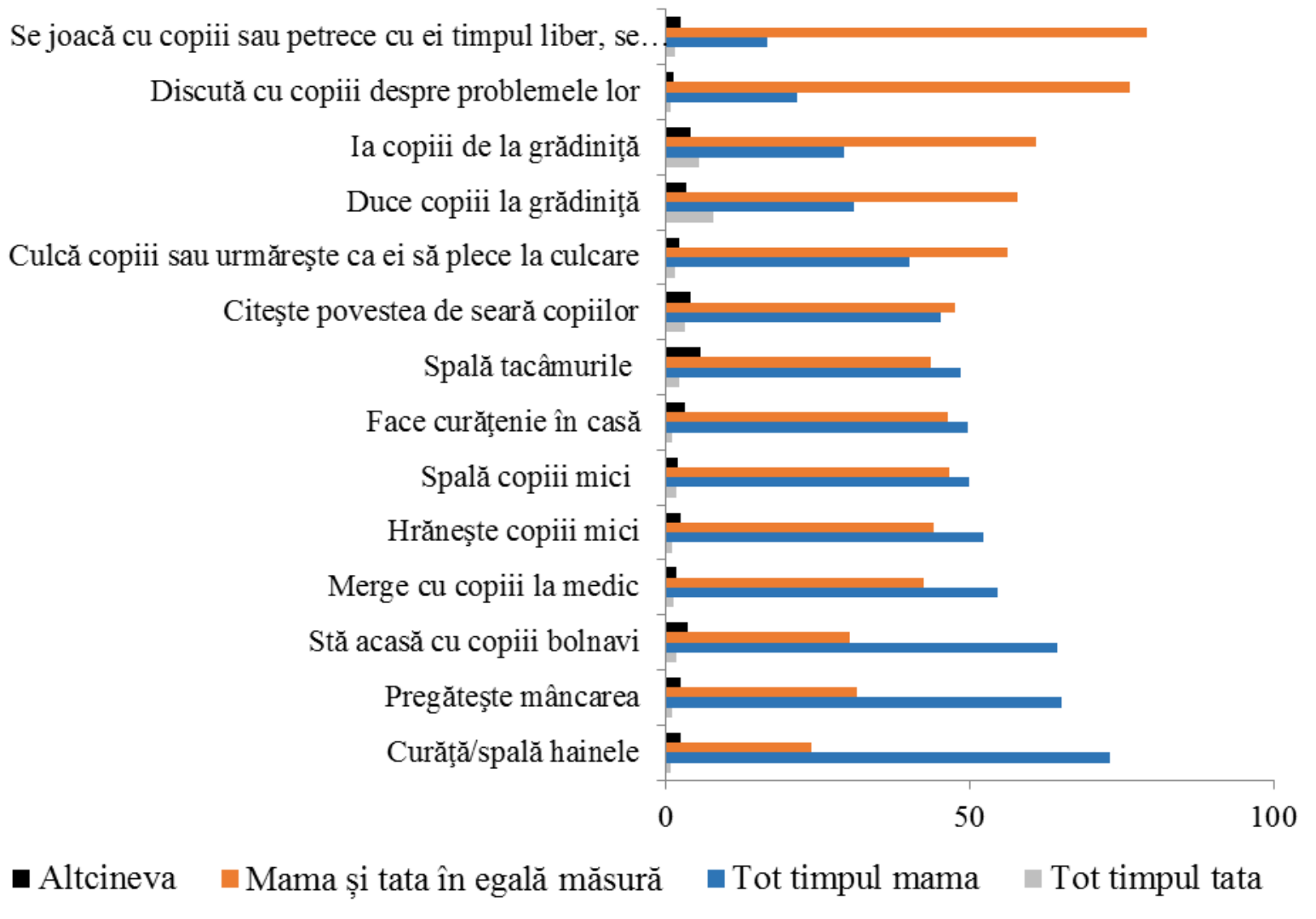

Sursa: Calculele autorilor

Figura 6. Implicarea taților în educația și îngrijirea copiilor

Studii numeroase arată că echilibrul între muncă şi viaţa privată este una dintre condiţiile fundamentale ale creşterii randamentului capitalului uman, întrucât contribuie la "descărcarea" unor griji şi la creşterea capacităţii de concentrare pe sarcina de muncă, la diminuarea stresului şi la protejarea sănătăţii psihice şi celei fizice. În plus, motivaţia şi loialitatea angajaţilor faţă de firmă, şi mai ales stabilitatea angajaţilor foarte performanţi, cresc dacă angajatorul contribuie la creşterea calităţii vieţii lor de familie. Datele studiului au evidenţiat însă existenţa unor impedimente la nivel de serviciu ce îngreunează crearea unui echilibru armonios dintre muncă și familie:

Necesitatea de a completa diverse registre, rapoarte în scopul oferirii învoirilor. "Chiar acum merg cu fetița să facem investigații. E necesar de fiecare dată să mă scrie intr-un registru special și să mă învoiesc de la 3 șefi. E foarte neplăcut, doar e sănătatea copilului, nu mă plimb de dragul plimbatului pe la policlinici. Lipsesc doar câteva ore”.

Imposibilitatea de a modifica orarul în cazuri imprevizibile.

Pierderea în salarizare din cauza lipsurilor motivate. "Când vine vorba de program flexibil, se taie din anumite facilități. Orele de muncă sunt la serviciu,.. "Învoiri ne dau, dar ne rețin din salariu. Dacă iau o zi, îti spune că îti taie 200 de lei, dar ei ne rețin mai mult".

Restricționări ale cadrului legal. "Dacă se întâmplă un accident în timpul orelor de muncă, chiar dacă el nu este în incinta întreprinderii, se consideră accident de muncă. Noi răspundem de viața și siguranța angajaților".

Respectarea normelor igienice și de siguranță în situația prestării muncii la domiciliu. "Trebuie să ne asigurăm că încăperea este luminoasă, cablurile sunt ok. Dar nu ne vom duce și vom verifica în casa lui".

Insuficienta reglementare legală a aspectelor ce țin de oferirea programelor flexibile și a muncii la domiciliu. "In lege nici nu se permite, dar nici nu se interzice munca la domiciliu". 
Obligativitatea de a respecta graficul de lucru. "Angajații din timp își planifică concediul de odihnă. Dacă la el apare o situație și el azi vrea concediu, noi îi oferim, dar încălcăm graficul de lucru, aceasta o să ne atenționeze Inspecția Muncii”.

Progresele în ceea ce privește o repartizare mai egală a sarcinilor de îngrijire a copiilor și a celor casnice între femei și bărbați sunt lente, iar diviziunea activităţilor domestice și de îngrijire a copiilor între bărbați și femei sunt foarte limitate. „El zice așa, eu sunt bărbat, eu fac bani. Tu ești mamă, tu stai acasă și ai grijă de copii”. „Tot ce-i legat de casă și copii eu îndeplinesc, iar tata face bani". La 70,6\% soțul a fost de acord cu ideea de a reveni la serviciu, la 65\% soțul i-a acordat ajutorul necesar pentru a reveni la serviciu, iar la 12,5\% dintre respondente soțul consideră că serviciul inluențează negativ îndeplinirea responsabilităților familiale. Aceasta denotă predominarea valorilor tradiţionale, conform cărora femeile ar trebui să acorde prioritate responsabilităţilor familiale, în timp ce bărbaţii ar trebui să-și îndeplinească rolul de aducător de venit în familie.

În concluzie vom menționa că includerea mamelor pe piaţa forței de muncă are efecte benefice asupra situației familiei, deoarece contribuie la suplinirea veniturilor și creșterea investițiilor în copii. Găsirea de către părinți a unui echilibru între muncă și viața personală este o problemă esențială pentru bunăstarea copiilor, deoarece atât sărăcia, cât și lipsa atenției pot dăuna dezvoltării copilului. Un echilibru bun reduce stresul parental și, prin urmare, aduce beneficii atât relației părinte-copil, cât și relației părinte-părinte. Lipsa serviciilor de creșă și educaţie timpurie, condițiile inadecvate din unele grădinițe contribuie ca cumularea rolurilor profesionale și parentale pentru mamele cu copii mici să fie dificilă. Unele femei aleg să părăsească piața forței de muncă pentru o perioadă mai lungă de timp, decât să se confrunte cu condiții de lucru care nu le permit săși echilibreze responsabilitățile profesionale și familiale. Astfel, mamele sunt în situaţia de a achita chiar o "amendă,, pentru maternitate [6]. Costurile ridicate ale unor servicii de îngrijire a copiilor mici (bone, grădinițe private), mai ales pentru lucrătorii cu venituri scăzute, reprezintă factori majori de descurajare a muncii. Rigiditatea cadrului legal contribuie ca mamele cu copii de vârstă preșcolară să se confrunte cu imposibilitatea angajatorilor de a le oferi careva condiții care să le permită combinarea armonioasă a vieții de familie cu cea profesională - programe flexibile de muncă, munca la domiciliu etc. Femeile continua să împărtășească dorința de a deveni mamă, însă amână această experiență la o vârstă mai înaintată, preocupându-se de căutarea unor oportunități de carieră și creștere profesională.

\section{Bibliografie}

1. Leovardis C., Cârcu L. Echilibrul dintre muncă, viaţa personală și educaţie în rândul studenților. O cercetare calitativă. Revista Română de Sociologie. București, 2018, Nr 1-2.

2. Zaharia D., Gavrilioaiei S. Flexibilitatea granițelor muncă-familie în context românesc. https://www.researchgate.net/publication/290447085_Flexibilitatea_granitelor_munca-

familie_in_context_romanesc.

Conciliation entre vie professionnelle et vie familiale. Allemagne 2004. Rapport de synthèse de l'évaluation par les pairs, Berlin 13-14 décembre 2004.

https://www.euro.centre.org > downloads > detail.

4. Erdamar G. Demirel H. Investigation of work-family, family-work conflict of the teachers. Procedia - Social and Behavioral Sciences. https://www.researchgate.net/publication/273851433_Investigation_of_Work-family_Familywork_Conflict_of the Teachers.

5. Higgins C., Duxbury L., Johnson K. Part-time work for women: does it really help balance work and family? Human Resource Management, 39(1), 2000.

6. Бирюкова С., Макаренцева А. Оценки «штрафа за материнство» в России. Население и экономика. Москва, 2017, Т. 1., № 1.

7. Исупова О. Материнская карьера: дети и трудовые стратегии. Социологические исследования, Москва, 2015, № 10. 